\title{
Foliar epidermis morphology in Quercus (subgenus Quercus, section Quercus) in Iran
}

\author{
PARISA PANAhI ${ }^{1,2}$, Ziba JAMZAD $^{2 *}$, Mohammad R. PourmaJidian ${ }^{1}$, \\ Asghar Fallah ${ }^{1}$, Mehdi Pourhashemi ${ }^{3}$ \\ ${ }^{1}$ Department of Forestry, Sari Agricultural Sciences and Natural Resources \\ University, P.O.Box: 737, Sari, Iran \\ ${ }^{2}$ Botany Research Division, Research Institute of Forests and Rangelands of \\ Iran, P.O.Box: 013185-116, Tehran, Iran \\ ${ }^{3}$ Forest Research Division, Research Institute of Forests and Rangelands of \\ Iran, P.O.Box: 13185-116, Tehran, Iran
}

\begin{abstract}
The foliar morphology of trichomes, epicuticular waxes and stomata in Quercus cedrorum, $Q$. infectoria subsp. boissieri, $Q$. komarovii, $Q$. longipes, $Q$. macranthera, $Q$. petraea subsp. iberica and $Q$. robur subsp. pedunculiflor $a$ were studied by scanning electron microscopy. The trichomes are mainly present on abaxial leaf surface in most species, but rarely they appear on adaxial surface. Five trichome types are identified as simple uniseriate, bulbous, solitary, fasciculate and stellate. The stomata of all studied species are of the anomocytic type, raised on the epidermis. The stomata rim may or may not be covered with epicuticular. The epicuticular waxes are mostly of the crystalloid type but smooth layer wax is observed in $Q$. robur subsp. pedunculiflora. Statistical analysis revealed foliar micromorphological features as been diagnostic characters in Quercus.
\end{abstract}

Keywords: Quercus, trichome, stoma, epicuticular wax, SEM

\section{Introduction}

Quercus is the most frequent genus of Fagaceae in the forests of Iran. Different species of oak are distributed in vast areas of the Zagros, Arasbaran and Hyrcanian Forests. In these forests, there is a remarkable morphological variation in the genus Quercus. All of Iran's native oaks belong to the subgenus Quercus, sections Quercus and Cerris. Species with dentate leaves belong to the section Cerris and lobed-leaves species, which are the object of this research, belong to the section Quercus.

\footnotetext{
* Corresponding author, e-mail: jamzad@rifr-ac.ir

Copyright ${ }^{\circledR} 2012$ by Acta Botanica Croatica, the Faculty of Science, University of Zagreb. All rights reserved.
} 
The first and the most complete study of Quercus in Iran, and also including the most important herbaria in Europe was made by DJAVANCHIR (1967), in his PhD thesis. He identified 9 taxa of lobed-leaves oak species (Quercus macranthera Fisch. and C. A. Mey.; Q. iberica Steven $=Q$. petraea (Matt.) Liebl. subsp. iberica (Steven) Krassiln.; Q. komarovii A.Camus $=Q$. longifolia K.Koch; $Q$. longipes Steven; $Q$. cedrorum Kotschy; $Q$. hass Kotschy $=Q$. robur L. subsp. pedunculiflora (K.Koch) Menitsky; Q. infectoria Oliv.; $Q$. infectoria Oliv. var. tenuicarpa Djav.-Khoie; $Q$. infectoria Oliv. var. pfaeffingeri Kotschy = Q. pfaeffingeri Kotschy). Four years later, another treatment of Quercus was published by MENITSKY in Flora Iranica (1971). He recognized 4 taxa in this group (Q. robur subsp. pedunculiflora; $Q$. infectoria Oliv. subsp. boissieri (Reut.) O. Schwarz; Q. petraea subsp. iberica; Q. macranthera). Since 1971, there have been many local studies and new collections revealing high diversity among the species of Sect. Quercus, so a comprehensive study of the genus is necessary. In the new review, micromorphological characters should be considered as well as investigations into ecological conditions, populations and possible hybridizations.

Trichome, stomata and wax characters demonstrated by previous investigators for American and European Quercus species, proved to be useful characters for species delimitation.

The use of trichome character in Quercus dates back to the taxonomic studies of DYAL (1936). She recognized glandular vs. non-glandular as two basic types of trichomes in oaks, then subdivided the latter into those with branches spreading from one point and those arising above one another along the hair axis. LUTZ (1938) described four different types and CAmus (1936-1954) developed a much more precise classification of seven types. Their widespread application to oak taxonomy has been increased through the use of scanning electron microscopy (SEM) so that HARDIN (1976, 1979a, b) and JONES (1986) were able to present a complete classification of oak trichomes and their terminology. Later, some researchers used SEM images for separation of Quercus species based on trichome types (BAČić 1981; Uzunova and Palamarev 1985, 1992a, b, 1993; Bussotti and Grossoni 1997; Lou and Zhou 2001; SCARELI-SANTOS et al. 2007).

Epicuticular waxes have considerable micromorphological diversity. Many of them are of great systematic significance (BARTHLOTT et al. 1998). The taxonomic significance of epicuticular waxes in Quercus has been studied by some researchers (BUSSOTTI and Grossoni 1997, Uzunova et al. 1997, SCARELI-SANTOS et al. 2007). The first comprehensive study of epicuticular waxes was made by DE BARY (1871). In the course of his light microscopic studies, he investigated about 60 species and classified epicuticular waxes into four categories. The most recent comprehensive overview of the classification of epicuticular waxes was given by BARTHLOTT et al. (1998).

The stomata of oak leaves have certain structural features which make them mutually distinguishable (NiKOLIĆ et al. 2003). Different characteristics of stomata such as density, dimension, location, subsidiary cell, guard cells and rim have been used for delimitation of oak species by some investigators (UzUnOva and PALAMAREV 1993, BussotTI and Grossoni 1997, UzunOva et al. 1997, Lou and ZHOU 2001).

The analysis of epidermal structures has proved to be of some help in taxonomy of oaks and provided a valuable set of analytical characters for species delimitation (THAMSON and 
Mohlenbrock 1979, Bačić 1981, Safou and Saint-Martin 1989, Manos 1993, Pénas Merino et al. 1994, Llamas et al. 1995, Uzunova et al. 1997, Fortini et al. 2009).

The present study was initiated to determine if quantifiable characters of trichomes, stomata and waxes could be combined with other morphological characters to produce a valid set of characters for recognizing Iranian oak species. In this research, we focused on the foliar epidermis structure of Quercus species of Sect. Quercus. Furthermore, we did a complete survey on habitats of Quercus species, their distribution patterns, populations and ecological conditions.

\section{Materials and methods}

The majority of specimens used in this study were obtained during several field trips to areas throughout the geographic range of species of the section Quercus in Iran. Ten individual trees were sampled for each taxon and some voucher specimens were prepared for each studied taxa. Materials and collecting data of examined taxa are listed in table 1.The voucher specimens are deposited in the Herbarium of the Research Institute of Forests and Rangelands of Iran (TARI). Furthermore, other previously collected specimens of TARI and the Herbarium of the Natural Resources Faculty, University of Tehran (NRF) were sampled.

The descriptions that follow are based on the mature condition of adaxial and abaxial leaf surfaces. All measurements were taken from trichomes and stomata occurring on a sample of $10 \mathrm{~mm}^{2}$ of surface midway between the base and apex, midvein and margin of leaves. Only fully expanded, undamaged leaves without signs of scarring or disease were examined. The leaf specimens were mounted onto aluminum stubs and sputter-coated with gold palladium for 5 minutes in a Humer II Sputtering Device. All leaf materials were pre-

Tab. 1. List of species and the collection data

\begin{tabular}{ll}
\hline Taxon & Collection data \\
\hline Quercus & Iran: Mazandaran, Siahbisheh, Djavanchir, 2054c (NRF) \\
macranthera & Iran: Ardabil, Khalkhal, Andebil Forest, 2100 m, Panahi and Pourhashemi \\
& 95102 (TARI) \\
& Iran: Golestan, 40 km South of Ali-Abad, Between Gorgan and Shah-Passand, \\
& 1800 m, Assadi 25591(TARI) \\
& Iran: East Azerbaijan, Kallibar, Protected region from Makidi to Veinagh, \\
& 1700 m, Wendelbo and Assadi 17057 (TARI) \\
& Iran: East Azerbaijan, Kallibar, Protected region from Makidi to Veinagh, \\
Q. petraea & Wendelbo and Assadi 17026 (TARI) \\
& Iran: Mazandaran, Chalous road, 2 km to Siahbisheh, 2450 m, Runemark and \\
& Mozaffarian, 28082 (TARI) \\
& Iran: East Azerbaijan, Arasbaran, Mountains south of Vaighan, 1200-1500 m, \\
& Assadi and masoumi, 20365(TARI) \\
& Iran: East Azerbaijan, Arasbaran, 1190 m, Panahi and Pourhashemi 95103 \\
& (TARI) \\
& Transcaucasia, Georgia, Adigeni, Flora of Ussr, Menitsky (TARI) \\
\hline
\end{tabular}


Panahi P., Jamzad Z., Pourmajidian M. R., Fallah A., Pourhashemi M.

Tab. 1. continued

\begin{tabular}{ll}
\hline Taxon & Collection data \\
\hline $\begin{array}{l}\text { Quercus } \\
\text { komarovii }\end{array}$ & Iran: East Azerbaijan, Kallibar, Arasbaran, Djavanchir 2052 (NRF) \\
& Iran: East Azerbaijan, Kallibar, Arasbaran, Djavanchir 2054 (NRF) \\
& Iran: East Azerbaijan, 10 km from Kallibar to Khodaafarin, 1850 m, Mozaffarian \\
& and Mohammadi 37616 (TARI) \\
& Iran: East Azerbaijan, Arasbaran, 1700 m, Panahi and Pourhashemi 95099 (TARI) \\
Q. longipes & Iran: East Azerbaijan, Oskou, $1492 \mathrm{~m}$, Panahi and Pourhashemi 95104 (TARI) \\
& Iran: West Azerbaijan, Khoy, Djavanchir 2054 (NRF) \\
& Iran: East Azerbaijan, Tabriz, Oskou, 1400 m, mozaffarian 72830 (TARI) \\
& Iran: East Azerbaijan, Oskou, Gunbarf village, 2240 m, Panahi and Pourhashemi \\
& 95105 (TARI)
\end{tabular}

Q. robur subsp. Iran: Kurdistan, Baneh-Marivan, Shipaneh-jow, Pirsharif cemetery, 1598 m, pedunculiflora Panahi and Pourhashemi 91401 (TARI)

Iran: Kurdistan, Baneh-Marivan, Bayan-darreh village, Sheikh musa cemetery, 1736 m, Panahi and Pourhashemi 91401 (TARI)

Iran: West Azerbaijan, Urmia, Bardeh- sou, Silvana, Sabeti 30992 (TARI)

Transcaucasia, Azerbaijania, dist Keessary, Flora of Ussr, Menitsky (TARI)

Q. cedrorum Iran: West Azerbaijan, Mirabad, Molla Allah cemetery, 1425 m, Panahi and Pourhashemi 95052 (TARI)

Iran: West Azerbaijan, Sardasht, Djavanchir, No number (NRF)

Iran: West Azerbaijan, Mirabad, Khedr-abad village, 1290 m, Panahi and Pourhashemi 95098 (TARI)

Q. infectoria Iran: Kurdistan, Baneh, Between Armardeh and Nirvan, 1523 m, Panahi and subsp. boissieri Pourhashemi 91433 (TARI)

var. boissieri Iran: Kurdistan, Baneh- Sardasht road, Djavanchir 2046 (NRF)

Iran: West Azerbaijan, Mirabad, Khedr-abad village, 1290 m, Panahi and Pourhashemi 95050 (TARI)

Iran: Kurdistan, $45 \mathrm{~km}$ on road from Saqqez to Baneh, 1900 m, Runemark and Mozaffarian 25929 (TARI)

Q. infectoria Iran: Kurdistan, Baneh, Belakeh, 1650 m, Djavanchir 25 (NRF)

subsp. boissieri Iran: Kurdistan, Baneh, Soleiman Bak cemetery, 1489 m, Panahi and

var. tenuicarpa Pourhashemi 91427 (TARI)

Iran: Kurdistan, Baneh, Between Armardeh and Nirvan, 1523 m, Panahi and

Pourhashemi 91435 (TARI)

Q. infectoria Iran: Kurdistan, Baneh, Mirhesam, 14-rigeh cemetery, $1550 \mathrm{~m}$, Panahi and subsp. boissieri Pourhashemi 95022 (TARI)

var. pfaeffingeri Iran: West Azerbaijan, Aliabad, on road of Piranshahr to Sardasht, 1200m, Zehzad and Siami 30983 (TARI)

Iran: Kurdistan, Baneh, Between Belakeh and Baneh, Djavanchir 2050h (NRF)

Iran: Kurdistan, Baneh, Soleiman Bak cemetery, 1489 m, Panahi and Pourhashemi 91421 (TARI) 
Tab. 2. Leaf micromorphological characters examined

\begin{tabular}{cl}
\hline Abbreviation and units & Description \\
\hline NSt-AbS & Number of stellate trichomes on abaxial surface \\
NFa-AbS & Number of fasciculate trichomes on abaxial surface \\
NSo-AbS & Number of solitary trichomes on abaxial surface \\
NSi-AbS & Number of simple- uniseriate trichomes on abaxial surface \\
NBu-AbS & Number of bulbose trichomes on abaxial surface \\
Tot-AbS & Total number of trichomes on abaxial surface \\
NSt-AdS & Number of stellate trichomes on adaxial surface \\
NFa-AdS & Number of fasciculate trichomes on adaxial surface \\
NSo-AdS & Number of solitary trichomes on adaxial surface \\
Tot-AdS & Total number of trichomes on adaxial surface \\
NStR-AbS & Number of stellate rays on abaxial surface \\
NFaR-AbS & Number of fasciculate rays on abaxial surface \\
LStR-AbS & Length of stellate rays on abaxial surface \\
LFaR-AbS & Length of fasciculate rays on abaxial surface \\
LSoR-AbS & Length of solitary rays on abaxial surface \\
LSt $(\mu \mathrm{m})$ & Length of stomata \\
WSt $(\mu \mathrm{m})$ & Width of stomata \\
StD $\left(\right.$ no. $\left.\mathrm{mm}{ }^{-2}\right)$ & Stomatal density \\
FSR $(\mu \mathrm{m})$ & Freedom of stomata rim \\
SAI & Stomatal area index
\end{tabular}

pared without pretreatment or critical point drying. The micromorphological characters of epidermal structures were observed and measured by a Hitachi (S-4160) SEM at an accelerating voltage of $15 \mathrm{KV}$. In total, 20 micromorphological characters were scored (Tab. 2). The number of each type present on a standard area of $1 \mathrm{~mm}^{2}$ was counted. The trichome ray length was measured from the point of divergence of the ray and base of the trichome. Terminology used for trichome types is based on HARDIN $(1976,1979 a)$. Identification of wax layer types has been done according to BARTHLOTT et al. (1998) and the freedom of rim was estimated following BRUSCHI et al. (2000). Stomatal density was then measured on a standard area of $1 \mathrm{~mm}^{2}$. Normality distribution of characters was assessed for all the 20 variables using the chi-square test $(\mathrm{p}<0.001)$ and ANOVA with post-hoc Student- Newman- Keuls mean comparisons was used to define the discrimination values for each variable. Furthermore, discriminant analysis was used to assess the degree of separation of the studied taxa by multivariate measurements.

\section{Results}

\section{Trichomes}

The studied oak species have different trichome types. We have identified five different trichome types in the examined taxa as follows: 
1. Simple-uniseriate: Thin-walled, unicellular or multicellular and uniseriate with different length diameter, number of cells and shape of cells. This trichome has been observed in all studied taxa except Quercus infectoria subsp. boissieri var. pfaeffingeri and $Q$. robur subsp. pedunculiflora (Figs. 1B, 1C, 1D).

2. Bulbous: Thin-walled, multicellular, uniseriate or irregularly multiseriate with enlarged, swollen cell or cells. This type has been observed only in Q. longipes (Fig. 1E).

3. Solitary: Single, long, usually straight and unicellular often thin-walled. There are two very distinct subtypes in this type. One has erect, long, unicellular hair on the lamina
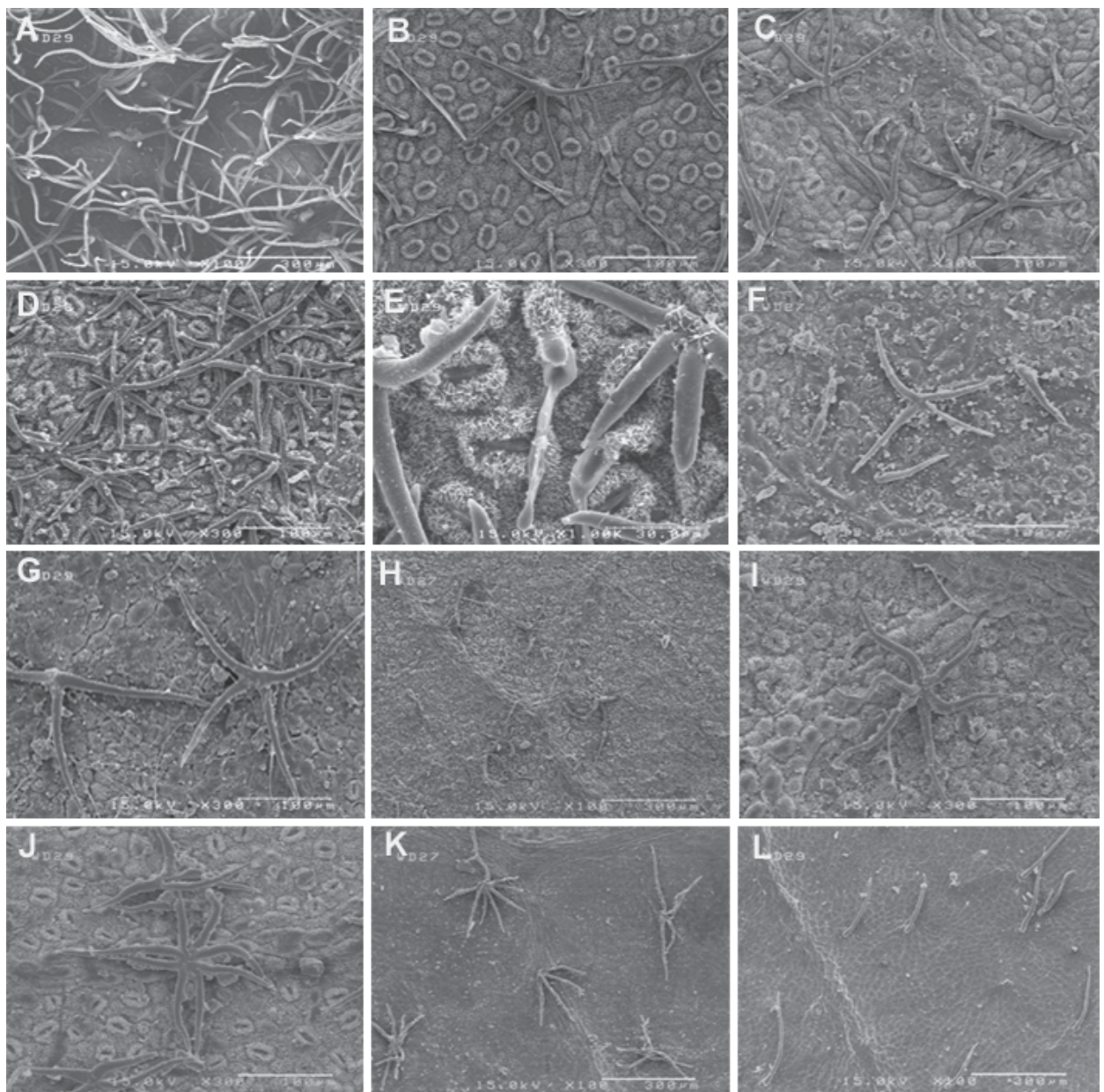

Fig. 1. SEM micrographs of trichomes in Quercus Sect. Quercus (A-L): Abaxial surface (A-J). Q. macranthera (A), Q. petraea subsp. iberica (B), Q. komarovii (C), Q. longipes (D-E), Q. robur subsp. pedunculiflora $(\mathrm{F})$, Q. cedrorum $(\mathrm{G})$, Q. infectoria subsp. boissieri var. boissieri $(\mathrm{H}), Q$. infectoria subsp. boissieri var. tenuicarpa (I), Q. infectoria subsp. boissieri var. pfaeffingeri (J), Adaxial surface (K-L). Q. infectoria subsp. boissieri var. pfaeffingeri $(\mathrm{K})$, Q. macranthera (L). Scale bar denotes $100 \mu \mathrm{m}(\mathrm{B}-\mathrm{D}, \mathrm{F}-\mathrm{J}) ; 300 \mu \mathrm{m}(\mathrm{A}, \mathrm{K}-\mathrm{L})$ and $30 \mu \mathrm{m}(\mathrm{E})$. 
and veins. The second subtype presents more or less appressed, long, often thinner-walled and sometimes wavy hair. They occur mostly on juvenile leaves and may persist along the petiole and midrib. We observed this type in all studied taxa (Figs. 1F, 1L).

4. Fasciculate: Erect, thick-walled cells, clustered and fused at base. This may be sessile, stipitate, or pedestaled. We have found this trichome type on the lamina of $Q$. macranthera and on the edge of the midrib in Q. infectoria subsp. boissieri var. boissieri (Figs. $1 \mathrm{~A}, 4 \mathrm{G})$.

5. Stellate: Usually thick-walled, with a single set of radiating, slender rays, projecting horizontally from a common center, sessile or stipitate. A few rays may be somewhat erect (e.g. $Q$. komarovii, Fig. 1C) but the general aspect is of an appressed trichome with the rays spreading in one plane roughly parallel to the epidermis (Q. longipes, Fig. 1D).

The trichome types identified may be present on the adaxial or on both surfaces of leaves. The differences of trichome types on the abaxial and adaxial surfaces of different species are summarized in table 3 .

Tab. 3. Trichome types of Quercus species Sect. Quercus

\begin{tabular}{lccccc}
\hline & \multicolumn{5}{c}{ Trichome types } \\
\cline { 2 - 6 } Taxon & $\begin{array}{c}\text { Simple- } \\
\text { uniseriate }\end{array}$ & Bulbous & Solitary & Fasciculate & Stellate \\
\hline Quercus macranthera & $-/+$ & $-/-$ & $+/+$ & $+/+$ & $-/-$ \\
Q. petraea subsp. iberica & $-/+$ & $-/-$ & $-/+$ & $-/-$ & $-/+$ \\
Q. komarovii & $-/+$ & $-/-$ & $-/+$ & $-/-$ & $-/+$ \\
$Q$. longipes & $-/+$ & $-/+$ & $-/+$ & $-/-$ & $-/+$ \\
Q. robur subsp. pedunculiflora & $-/-$ & $-/-$ & $-/+$ & $-/-$ & $-/+$ \\
Q. cedrorum & $-/+$ & $-/-$ & $-/+$ & $-/-$ & $-/+$ \\
Q. infectoria subsp. boissieri var. boissieri & $-/+$ & $-/-$ & $-/+$ & $-/+$ & $-/+$ \\
Q. infectoria subsp. boissieri var. tenuicarpa & $-/+$ & $-/-$ & $-/+$ & $-/+$ & $-/+$ \\
Q. infectoria subsp. boissieri var. pfaeffingeri & $-/-$ & $-/-$ & $-/+$ & $-/+$ & $+/+$ \\
\hline
\end{tabular}

Adaxial surface/Abaxial surface. $-=$ absent,$+=$ present

\section{Waxes}

Two main types and three subtypes of epicuticular waxes were recognized as follows:

I. Crystalloids: Distinct wax projections, usually with a characteristic shape, size and orientation towards the surface, protruding from the ubiquitous wax film (BARTHLOTT et al. 1998). Two subtypes are identified within this type as follows:

a. Membranous platelets: Flat, membranous interconnected crystalloids, protruding from the surface at an acute angle, often with threadlike extensions (Fig. 2F).

b. Irregular platelets: Flat crystalloids with irregular margin, protruding perpendicularly from the surface (Figs. 2A-D, 2G-I). 

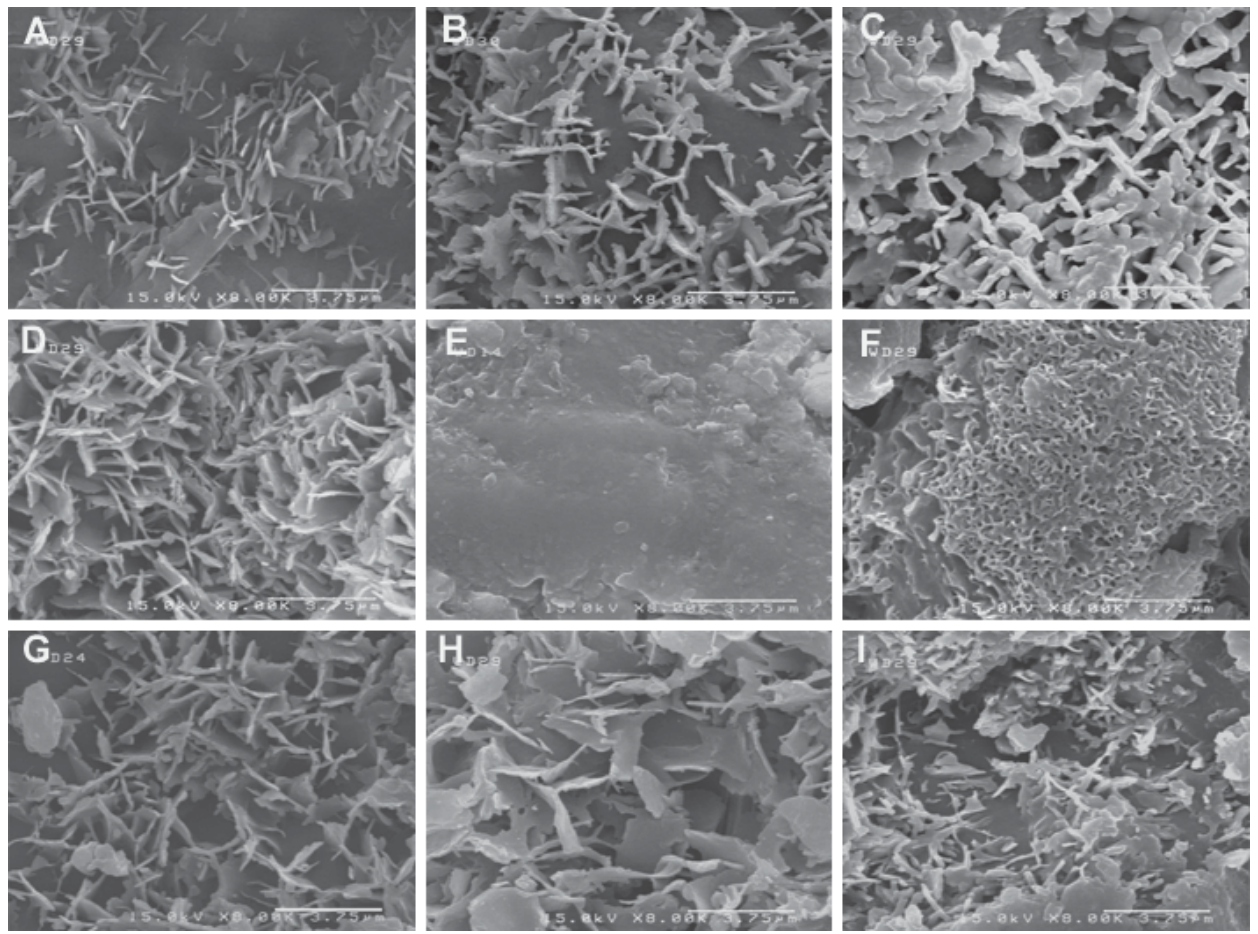

Fig. 2. SEM micrographs of wax in Quercus Sect. Quercus: Q. macranthera (A), Q. petraea subsp. iberica (B), Q. komarovii (C), Q. longipes (D), Q. robur subsp. pedunculiflora (E), Q. cedrorum $(\mathrm{F}), Q$. infectoria subsp. boissieri var. boissieri $(\mathrm{G}), Q$. infectoria subsp. boissieri var. tenuicarpa $(\mathrm{H})$, Q. infectoria subsp. boissieri var. pfaeffingeri (I), Scale bar in A-I denotes $3.75 \mu \mathrm{m}$.

II. Layers and crusts: Continuous coverings with a considerable thickness, ca.0.5-10 $\mu \mathrm{m}$. It should be noted that most crusts are continuous coverings from the beginning, but some are the product of the erosion of crystalloids. Sometimes contaminated smooth layers may appear as crusts (BARTHLOTT et al. 1998).

Several subtypes have been identified within this type but we observed one subtype as follows:

Smooth layers: Continuous covering usually less than $1 \mu \mathrm{m}$ thick without a prominent surface sculpturing (Fig. 2E).

\section{Stomata}

According to the arrangement of stomata subsidiary cells, we recognized only anomocytic type. This type of stomata has epidermal cells around the guard cells not distinguishable from other epidermal cells. We identified three stomata shapes as follows: elliptical (Quercus cedrorum, Fig. 3F), roundish (Q. infectoria subsp. boissieri var. pfaeffingeri, Fig. 3I) and rounded (Q. infectoria subsp. boissieri var. tenuicarpa, Fig. $3 \mathrm{H})$. Stomata were raised above the epidermal surface in all cases. The rims of the stomata were covered by 

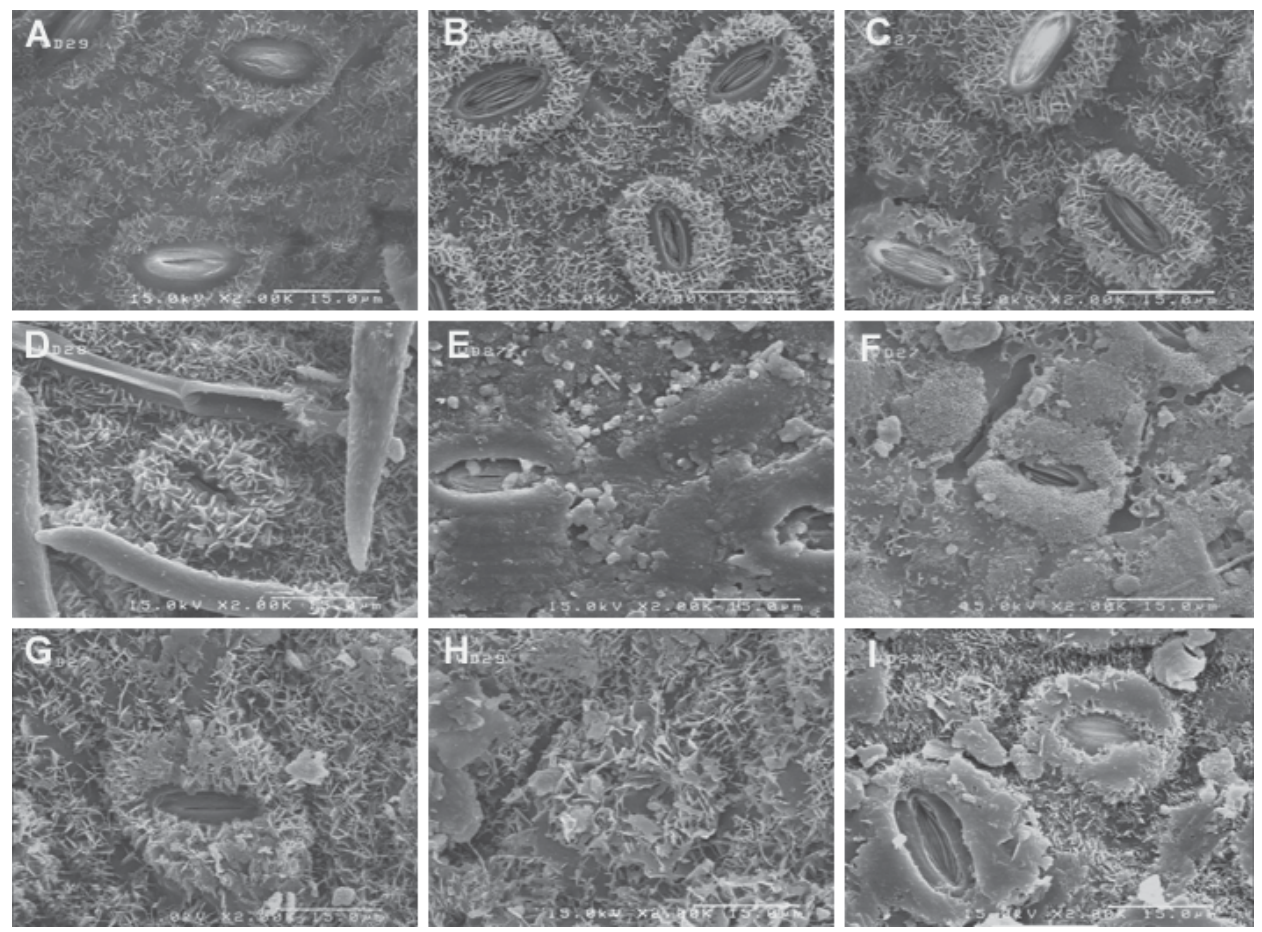

Fig. 3. SEM micrographs of stomata in Quercus Sect. Quercus: Q. macranthera (A), Q. petraea subsp. iberica (B), Q. komarovii (C), Q. longipes (D), Q. robur subsp. pedunculiflora (E), Q. cedrorum (F), Q. infectoria subsp. boissieri var. boissieri (G), Q. infectoria subsp. boissieri var. tenuicarpa $(\mathrm{H}), Q$. infectoria subsp. boissieri var. pfaeffingeri $(\mathrm{I})$, Scale bar in A-I denotes $15 \mu \mathrm{m}$.

epicuticular waxes of crystalloids type in some examined taxa like $Q$. longipes (Fig. 3D), while the others had uncovered rims (e.g. Q. petraea subsp. iberica, Fig. 3B). In one case, the rim and pore were entirely covered by crystalloids, so that the pore was invisible $(Q$. infectoria subsp. boissieri var. tenuicarpa, Fig. $3 \mathrm{H})$.

\section{Univariate analysis}

There were significant differences among studied taxa (ANOVA, $\mathrm{p}<0.001$ ) for all micromorphological characters (Tab. 4). SNK tests indicated that the number of fasciculate trichomes on the abaxial surface was responsible for providing three groups: $Q$. $m a$ cranthera with highest value, three varieties of $Q$. infectoria subsp. boissieri with a low number of fasciculate trichomes, while $Q$. komarovii, $Q$. petraea subsp. iberica, $Q$. cedrorum, $Q$. longipes and $Q$. robur subsp. pedunculiflora had no fasciculate trichomes. The presence of bulbous trichomes on the abaxial surface and the highest number of stellate trichomes on the abaxial surface distinguishes $Q$. longipes from other examined taxa. Quercus macranthera and Q. infectoria subsp. boissieri var. pfaeffingeri had trichomes on the adaxial surfaces of fasciculate, stellate and solitary types. 
Tab. 4. ANOVA results of leaf micromorphological characters. Variables and Units are specified in Table 2.

\begin{tabular}{|c|c|c|c|c|c|c|c|c|c|c|c|c|c|}
\hline variables & $\mathrm{df}$ & f & Descri & ptive & $\begin{array}{c}Q . \\
\text { macranthera }\end{array}$ & $\begin{array}{l}\text { Q. petraea } \\
\text { subsp. } \\
\text { iberica }\end{array}$ & $\begin{array}{c}Q . \\
\text { komarovii }\end{array}$ & Q. longipes & $\begin{array}{c}\text { Q. robur } \\
\text { subsp. } \\
\text { pedunculiflora }\end{array}$ & $\underset{\text { cedrorum }}{Q .}$ & $\begin{array}{c}\text { Q. infectoria } \\
\text { subsp. } \\
\text { boissieri var. } \\
\text { boissieri }\end{array}$ & $\begin{array}{c}\text { Q. infectoria } \\
\text { subsp. } \\
\text { boissieri var. } \\
\text { tenuicarpa }\end{array}$ & $\begin{array}{c}\text { Q. infectoria } \\
\text { subsp. } \\
\text { boissieri var. } \\
\text { pfaeffingeri }\end{array}$ \\
\hline & & & Mean & SD & Mean \pm SD & Mean \pm SD & Mean \pm SD & Mean \pm SD & Mean \pm SD & Mean \pm SD & Mean \pm SD & Mean \pm SD & Mean \pm SD \\
\hline NSt-AbS & 8 & $1398^{*}$ & 17 & 22 & $0^{\mathrm{a}}$ & $11 \pm 2^{\mathrm{b}}$ & $47 \pm 3^{c}$ & $65 \pm 3^{d}$ & $8 \pm 2^{\mathrm{ef}}$ & $8 \pm 2^{\mathrm{e}}$ & $4 \pm 1^{g}$ & $5 \pm 1^{\mathrm{efg}}$ & $4 \pm 2^{\mathrm{fg}}$ \\
\hline $\mathrm{NFa}-\mathrm{AbS}$ & 8 & $714 *$ & 4 & 9 & $28 \pm 3^{a}$ & $0^{\mathrm{b}}$ & $0^{\mathrm{b}}$ & $0^{\mathrm{b}}$ & $0^{\mathrm{b}}$ & $0^{\mathrm{b}}$ & $3 \pm 1^{\mathrm{c}}$ & $3 \pm 1^{\mathrm{c}}$ & $2 \pm 1^{\mathrm{c}}$ \\
\hline NSo-AbS & 8 & $62 *$ & 3 & 2 & $4 \pm 1^{\mathrm{a}}$ & $0^{\mathrm{b}}$ & $2 \pm 1^{\mathrm{c}}$ & $2 \pm 1^{\mathrm{c}}$ & $7 \pm 7^{\mathrm{d}}$ & $2 \pm 1^{\mathrm{c}}$ & $3 \pm 1^{\mathrm{c}}$ & $2 \pm 0^{\mathrm{c}}$ & $2 \pm 1^{c}$ \\
\hline NSi-AbS & 8 & $265^{*}$ & 15 & 12 & $32 \pm 3^{a}$ & $33 \pm 3^{a}$ & $16 \pm 3^{\mathrm{bc}}$ & $20 \pm 2^{\mathrm{b}}$ & $0^{\mathrm{d}}$ & $2 \pm 1^{d}$ & $19 \pm 4^{\mathrm{b}}$ & $15 \pm 3^{\mathrm{c}}$ & $0^{\mathrm{d}}$ \\
\hline NBu-AbS & 8 & $376^{*}$ & 1 & 2 & $0^{\mathrm{a}}$ & $0^{\mathrm{a}}$ & $0^{\mathrm{a}}$ & $6 \pm 1^{\mathrm{b}}$ & $0^{\mathrm{a}}$ & $0^{\mathrm{a}}$ & $0^{\mathrm{a}}$ & $0^{\mathrm{a}}$ & $0^{\mathrm{a}}$ \\
\hline Tot-AbS & 8 & $771 *$ & 40 & 28 & $65 \pm 4^{\mathrm{a}}$ & $44 \pm 4^{\mathrm{b}}$ & $65 \pm 4^{\mathrm{a}}$ & $93 \pm 3^{c}$ & $14 \pm 3^{\mathrm{d}}$ & $12 \pm 2^{\mathrm{de}}$ & $29 \pm 5^{\mathrm{f}}$ & $25 \pm 3^{\mathrm{f}}$ & $8 \pm 2^{\mathrm{e}}$ \\
\hline NSt-AdS & 8 & $565^{*}$ & 1 & 4 & $0^{\mathrm{a}}$ & $0^{\mathrm{a}}$ & $0^{\mathrm{a}}$ & $0^{\mathrm{a}}$ & $0^{\mathrm{a}}$ & $0^{\mathrm{a}}$ & $0^{\mathrm{a}}$ & $0^{\mathrm{a}}$ & $12 \pm 2^{b}$ \\
\hline NFa-AdS & 8 & $52^{*}$ & 0 & 1 & $2 \pm 1^{\mathrm{a}}$ & $0^{\mathrm{b}}$ & $0^{\mathrm{b}}$ & $0^{\mathrm{b}}$ & $0^{\mathrm{b}}$ & $0^{\mathrm{b}}$ & $0^{\mathrm{b}}$ & $0^{\mathrm{b}}$ & $0^{\mathrm{b}}$ \\
\hline NSo-AdS & 8 & $312 *$ & 1 & 2 & $5 \pm 1^{\mathrm{a}}$ & $0^{\mathrm{b}}$ & $0^{\mathrm{b}}$ & $0^{\mathrm{b}}$ & $0^{\mathrm{b}}$ & $0^{\mathrm{b}}$ & $0^{\mathrm{b}}$ & $0^{\mathrm{b}}$ & $0^{\mathrm{b}}$ \\
\hline Tot-AdS & 8 & $401 *$ & 2 & 4 & $7 \pm 1^{\mathrm{a}}$ & $0^{\mathrm{b}}$ & $0^{\mathrm{b}}$ & $0^{\mathrm{b}}$ & $0^{\mathrm{b}}$ & $0^{\mathrm{b}}$ & $0^{\mathrm{b}}$ & $0^{\mathrm{b}}$ & $12 \pm 2^{\mathrm{c}}$ \\
\hline NStR-AbS & 8 & $24 *$ & 3 & 2 & $0^{\mathrm{a}}$ & $3 \pm 1^{\mathrm{b}}$ & $4 \pm 1^{\text {bc }}$ & $4 \pm 2^{b c}$ & $3 \pm 1^{\mathrm{b}}$ & $3 \pm 1^{\mathrm{b}}$ & $3 \pm 1^{\mathrm{b}}$ & $5 \pm 1^{\mathrm{cd}}$ & $6 \pm 2^{\mathrm{d}}$ \\
\hline NFaR-AbS & 8 & $60 *$ & 2 & 2 & $5 \pm 2^{\mathrm{a}}$ & $0^{\mathrm{b}}$ & $0^{\mathrm{b}}$ & $0^{\mathrm{b}}$ & $0^{\mathrm{b}}$ & $0^{\mathrm{b}}$ & $3 \pm 1^{c}$ & $3 \pm 1^{c}$ & $3 \pm 1^{c}$ \\
\hline LStR-AbS & 8 & $52 *$ & 96 & 51 & $0^{\mathrm{a}}$ & $89 \pm 13^{\mathrm{b}}$ & $82 \pm 9^{\mathrm{bc}}$ & $52 \pm 10^{\mathrm{c}}$ & $98 \pm 18^{\text {bd }}$ & $132 \pm 23^{\mathrm{de}}$ & $156 \pm 43^{\mathrm{e}}$ & $105 \pm 18^{\text {bd }}$ & $150 \pm 28^{\mathrm{e}}$ \\
\hline LFaR-AbS & 8 & $111 *$ & 119 & 144 & $341 \pm 91^{a}$ & $0^{\mathrm{b}}$ & $0^{\mathrm{b}}$ & $0^{\mathrm{b}}$ & $0^{\mathrm{b}}$ & $0^{\mathrm{b}}$ & $277 \pm 78^{\mathrm{ac}}$ & $236 \pm 29^{\mathrm{c}}$ & $218 \pm 44^{\mathrm{c}}$ \\
\hline LSoR-AbS & 8 & $47^{*}$ & 243 & 105 & $381 \pm 83^{\mathrm{a}}$ & $247 \pm 73^{\mathrm{b}}$ & $237 \pm 70^{\mathrm{b}}$ & $339 \pm 9^{\mathrm{ac}}$ & $93 \pm 11^{\mathrm{d}}$ & $152 \pm 10^{\mathrm{d}}$ & $307 \pm 27^{\mathrm{c}}$ & $305 \pm 34^{\mathrm{bc}}$ & $128 \pm 9^{\mathrm{d}}$ \\
\hline LSt & 8 & $14 *$ & 24 & 3 & $22 \pm 2^{\mathrm{ab}}$ & $25 \pm 2^{\text {bcd }}$ & $21 \pm 2^{\mathrm{a}}$ & $24 \pm 2^{\mathrm{abc}}$ & $23 \pm 2^{\mathrm{abc}}$ & $20 \pm 1^{\mathrm{a}}$ & $27 \pm 3^{d}$ & $26 \pm 1^{\mathrm{cd}}$ & $25 \pm 2^{\text {bcd }}$ \\
\hline WSt & 8 & $36^{*}$ & 18 & 3 & $16 \pm 1^{\mathrm{a}}$ & $18 \pm 1^{\mathrm{b}}$ & $18 \pm 2^{\mathrm{b}}$ & $18 \pm 2^{\mathrm{b}}$ & $15 \pm 2^{\mathrm{a}}$ & $14 \pm 1^{\mathrm{a}}$ & $20 \pm 2^{\mathrm{b}}$ & $23 \pm 1^{c}$ & $20 \pm 1^{\mathrm{b}}$ \\
\hline StD & 8 & $54 *$ & 191 & 38 & $204 \pm 19^{\mathrm{a}}$ & $194 \pm 7^{\mathrm{ab}}$ & $177 \pm 5^{\mathrm{bc}}$ & $169 \pm 10^{\mathrm{bc}}$ & $207 \pm 19^{\mathrm{a}}$ & $163 \pm 13^{\mathrm{c}}$ & $277 \pm 9^{\mathrm{d}}$ & $174 \pm 32^{\mathrm{bc}}$ & $156 \pm 10^{c}$ \\
\hline FSR & 8 & $250^{*}$ & 6 & 3 & $8 \pm 1^{\mathrm{a}}$ & $9 \pm 0^{\mathrm{b}}$ & $7 \pm 1^{a}$ & $7 \pm 0^{\mathrm{a}}$ & $5 \pm 1^{\mathrm{c}}$ & $4 \pm 0^{\mathrm{d}}$ & $4 \pm 1^{d}$ & $0^{\mathrm{e}}$ & $8 \pm 1^{a}$ \\
\hline SAI & 8 & $47 *$ & 4557 & 1275 & $4554 \pm 601^{\mathrm{a}}$ & $4777 \pm 429^{\mathrm{a}}$ & $3631 \pm 510^{\mathrm{bc}}$ & $4013 \pm 436^{\mathrm{bc}}$ & $4770 \pm 627^{\mathrm{a}}$ & $3346 \pm 283^{\mathrm{b}}$ & $7523 \pm 848^{\mathrm{d}}$ & $4475 \pm 781^{\mathrm{ab}}$ & $3925 \pm 210^{\mathrm{abc}}$ \\
\hline
\end{tabular}


On the other hand, a freedom of stomatal rim enables $Q$. infectoria subsp. boissieri var. tenuicarpa (stomatal rim completely covered) to be distinguished from the other taxa (stomatal rim covered to varying degrees). Furthermore, high value of stomatal density distinguishes $Q$. infectoria subsp. boissieri var. boissieri from other studied taxa.

\section{Multivariate analysis}

Discriminant analysis revealed that the three functions represented $87.6 \%$ of the total variation in the data set (Tab. 5). The first discriminant function accounted for $49.7 \%$ of the total variance. The standardized coefficients of function 1 were highest for the number of stellate trichomes on the abaxial surface, number of solitary trichomes on the adaxial surface and number of fasciculate trichomes on the abaxial surface. Function 2 represented another $26.9 \%$ of the total variance. This function was related to number of solitary trichomes on the adaxial surface, number of stellate trichomes on the abaxial surface and number of fasciculate trichomes on the abaxial surface, respectively. Function 3 accounted for $11 \%$ of the total variation and belonged to number of stellate trichomes on the adaxial surface, the number of bulbous trichomes on the abaxial surface and the number of fasciculate trichomes on the abaxial surface (Fig. 4). Overall misclassification was zero.

Tab. 5. Standardized coefficients for the first three discriminant functions of means micromorphological characters

\begin{tabular}{cccc}
\hline variables & Function 1 & Function 2 & Function 3 \\
\hline LStR-AbS & -.042 & -.201 & .209 \\
LSoR-AbS & .397 & .247 & .021 \\
LFaR-AbS & .302 & .129 & -.025 \\
NSt-AbS & -.723 & .494 & .190 \\
NFa-AbS & .662 & .489 & .279 \\
NSo-AbS & -.189 & .031 & -.199 \\
NSi-AbS & -.023 & .396 & -.202 \\
NBu-AbS & -.269 & .345 & .285 \\
NSt-AdS & .194 & -.402 & .839 \\
NSo-AdS & .669 & .501 & .253 \\
WSt & .006 & -.150 & .061 \\
StD & .183 & .060 & -.217 \\
FSR & -.133 & .039 & .221 \\
\hline
\end{tabular}

\section{Description of taxa}

Quercus macranthera Fisch. and C.A.Mey.

Deciduous large tree, up to $25 \mathrm{~m}$ high, with spreading crown, gray-brown thick bark, leaves with long persistent stipules. This species is characterized with dense trichomes of different types on leaf surfaces. Both abaxial and adaxial surfaces are covered with trichomes, but the density and variability of trichomes is higher on abaxial surface. The most 


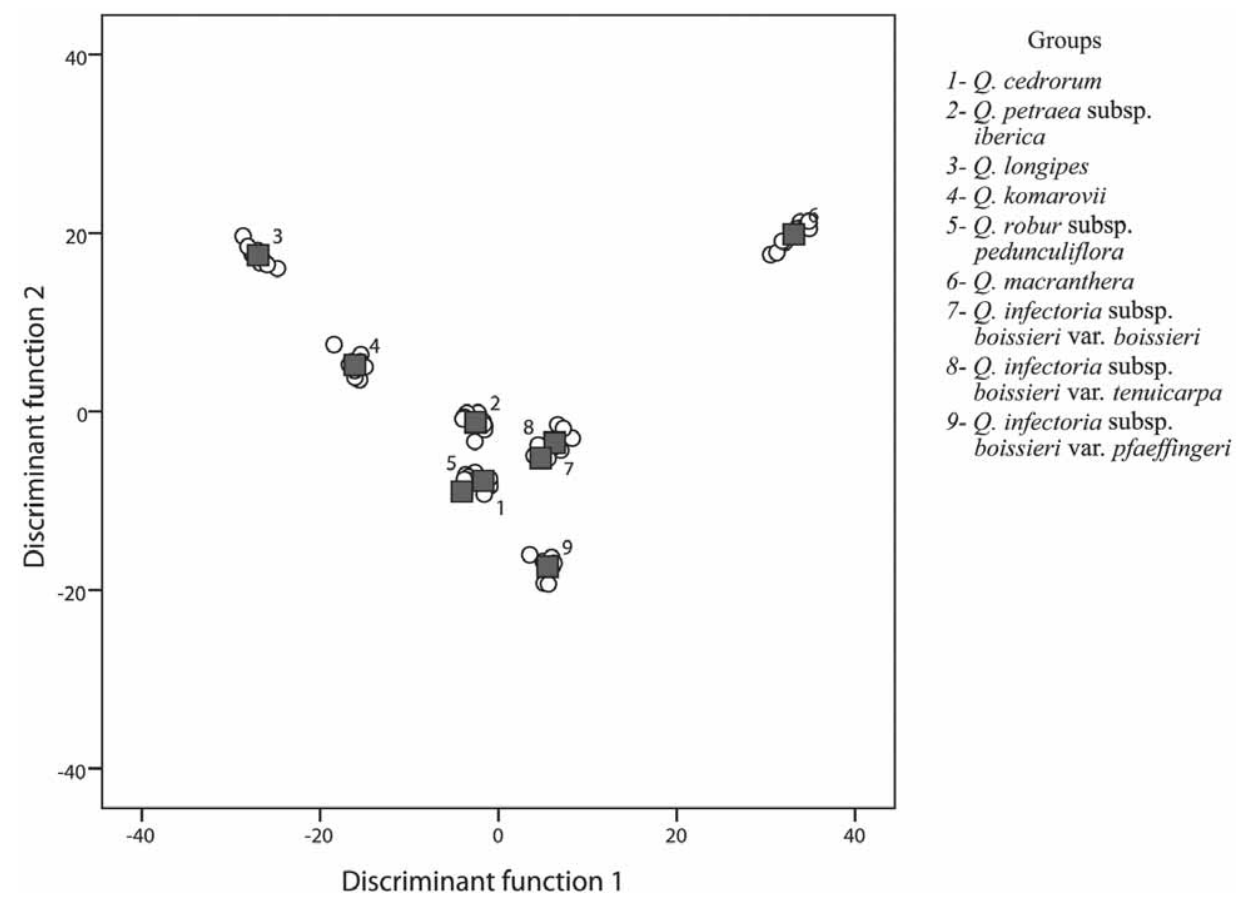

Fig. 4. Canonical discriminant functions of micromorphological characters of studied taxa: $Q$. cedrorum (1), Q. petraea subsp. iberica (2), Q. longipes (3), Q. komarovii (4), Q. robur subsp. pedunculiflora (5), Q. macranthera (6), Q. infectoria subsp. boissieri var. boissieri (7), Q. infectoria subsp. boissieri var. tenuicarpa (8), Q. infectoria subsp. boissieri var. pfaeffingeri (9). Black squares represent centered groups of closely related taxa.

frequent trichomes on abaxial surface are pedestaled-fasciculate and stipitate-fasciculate. These trichomes have $2-8$ very long rays $(190-455 \mu \mathrm{m})$. They are not spread on the surface of the leaf (Fig. 1A). Stipitate-fasciculate trichomes are more abundant than pedestaled-fasciculate. Furthermore, simple-uniseriate hairs are abundant. On adaxial surface trichomes are restricted only to a few solitary and 2-rayed fasciculate forms, irregularly and sparsely scattered on epidermal surface (Fig. 1L). On the main veins, the solitary, pedstaled-fasciculate and 2-rayed fasciculate trichomes were frequently found. Midrib is covered completely with long solitary (more than $300 \mu \mathrm{m}$ ) and fasciculate trichomes with often 2-3 long rays (Fig. 5A). The waxes on the abaxial surface are irregular platelets (Fig. 2A). They are not very densely and evenly distributed. The platelets are shorter in open spaces between stomata and are also eroded. The stomata are raised, elliptical and the rim is uncovered (Fig. 3A).

Quercus petraea (Matt.) Liebl. subsp. iberica (Steven) Krassiln.

Deciduous medium size tree, up to $12 \mathrm{~m}$ high, in uplands, large tree up to $18 \mathrm{~m}$ height in lowlands, with spreading crown, bright and cracked bark, branches glabrous. Leaves have short persistent stipules. Simple-uniseriate multicellular hairs with 2-3 cells and stellate trichomes with 2-4 (often 4$)$ symmetric short rays $(75-120 \mu \mathrm{m})$ are spread regularly on the 

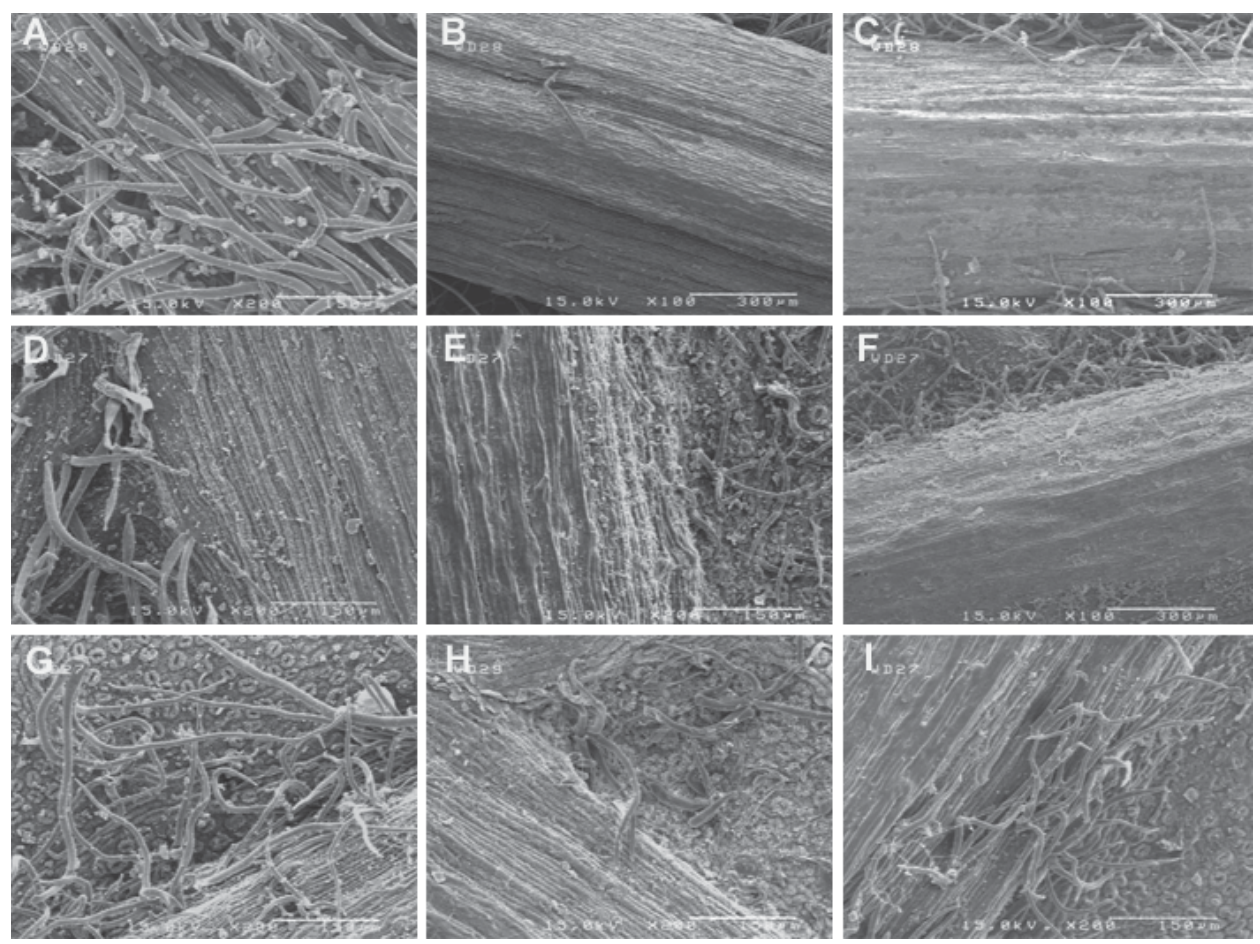

Fig. 5. SEM micrographs of midrib in Quercus Sect. Quercus: Q. macranthera (A), Q. petraea subsp. iberica (B), Q. komarovii (C), Q. longipes (D), Q. robur subsp. pedunculiflora (E), Q. cedrorum $(\mathrm{F}), Q$. infectoria subsp. boissieri var. boissieri $(\mathrm{G}), Q$. infectoria subsp. boissieri var. tenuicarpa $(\mathrm{H}), Q$. infectoria subsp. boissieri var. pfaeffingeri $(\mathrm{I})$, Scale bar denotes 300 $\mu \mathrm{m}(\mathrm{B}, \mathrm{C}, \mathrm{F})$ and $150 \mu \mathrm{m}(\mathrm{A}, \mathrm{D}-\mathrm{E}, \mathrm{G}-\mathrm{I})$.

surface of the leaf (Fig. 1B). There are only a few long solitary hairs (more than $200 \mu \mathrm{m}$ ) on the midrib (Fig. 5B). There is no trichome on the adaxial surface. The waxes on the abaxial surface are irregular platelets that do not necessarily cover the entire leaf surface, leaving empty spaces between individual platelets (Fig. 2B). The stomata are elliptical, raised and covered by a crown of wax platelets; the rim is elliptical and uncovered (Fig. 3B).

\section{Quercus komarovii A. Camus}

Deciduous small tree or shrub, up to $5 \mathrm{~m}$ high, with spreading crown, brown-red young branches and leathery leaves. The abaxial surface is covered by stellate trichomes with $2-4$ (often 4) short rays (60-95 $\mu \mathrm{m}$ ), completely symmetric (Fig. 1C). Usually the middle rays are erect and the others spread roughly parallel to the epidermis. This trichome type is denser near the midrib. On the midrib a few solitary hairs are observed (Fig. 5C). There are a few simple-uniseriate trichomes on the abaxial surface. Densely irregular wax platelets have been observed on the abaxial surface (Fig. 2C), and flat layer type wax is also observed in some sections of surface and around some stomata. The stomata are elliptical and raised; the rim is uncovered (Fig. 3C). 


\section{Quercus longipes Steven}

Deciduous large tree, 15-20 m high, with spreading crown, gray-brown branches and large leathery dark-green leaves. The abaxial surface has high trichome density. Different types of trichomes are found on abaxial surface. Stellate with 2-8 (mostly 4) symmetric short rays $(35-70 \mu \mathrm{m})$, appressed to the surface of the leaf are the most frequent type. Simple-uniseriate hairs are unicellular or multicellular (Fig. 1D). A few bulbous trichomes have also been seen (Fig. 1E). There were no trichomes on the adaxial surface and on the midrib, but long solitary trichomes (more than $300 \mu \mathrm{m}$ ) are distributed sparsely on the midrib edges (Fig. 5D). The wax type on the abaxial surface is that of irregular platelets, very densely and evenly distributed over the epidermal surface (Fig. 2D). The stomata are elliptical and raised; the rim is completely covered with wax so that only the pore is visible (Fig. 3D).

\section{Quercus robur L. subsp. pedunculiflora (K. Koch) Menitsky}

Deciduous large tree, up to $18 \mathrm{~m}$ high, with spreading crown, thick and cracked bark. Leaves are smooth, with short petioles. On abaxial surface, few stellate trichomes with symmetric $2-4$ rays measuring $60-130 \mu \mathrm{m}$, sparsely spread on the surface of the leaf intermixed with a few short solitary hairs $(80-115 \mu \mathrm{m})$ were observed (Fig. 1F). A few solitary trichomes are present on midrib (Fig. 5E). The waxes are of smooth layer type (Fig. 2E). The stomata are elliptical and completely raised. The guard cells of stomata are covered with smooth layer waxes (Fig. 3E).

\section{Quercus cedrorum Kotschy}

Deciduous small tree, 6-9 m high, with spreading crown and long branches. A few sparsely distributed multicellular simple-uniseriate, solitary and stellate trichomes were observed only on the abaxial surface. The stellate trichomes have 2-4 (often 4) rays measuring $80-160 \mu \mathrm{m}$, fairly asymmetric and completely spread on the surface of the leaf. The solitary hairs are 135-170 $\mu \mathrm{m}$ long (Fig. 1G). No trichomes have been observed on the midrib, but there are some solitary and stellate trichomes on the midrib edges (Fig. 5F). Crystalloid waxes in the shape of membraneous platelets cover the abaxial surface (Fig. 2F). The stomata are markedly elliptical and raised; the rim is visible and without wax (Fig. 3F).

\section{Quercus infectoria Oliv. subsp. boissieri (Reut.) O. Schwarz var. boissieri}

Deciduous small tree, 6-9 m high, with spreading crown, gray, cracked bark and leathery leaves. Two types of trichome were observed on the abaxial surface: sparse trichomes as stellate with $2-5$ rays $(90-210 \mu \mathrm{m})$ and a few multicellular simple-uniseriate trichomes (Fig. 1H). Long solitary (270-350 $\mu \mathrm{m})$ and fasciculate trichomes with 2-4 erect long rays $(215-400 \mu \mathrm{m})$ were observed on the midrib (Fig. 5G). The irregular platelets waxes are evenly but irregularly distributed on the abaxial surface (Fig. 2G). The stomata are elliptical and raised; the rim is completely covered with wax but the pore is visible (Fig. 3G).

Quercus infectoria Oliv. subsp. boissieri (Reut.) O.Schwarz var. tenuicarpa (Djav.Khoie) Jamzad et Panahi

Deciduous small tree, up to $10 \mathrm{~m}$ high, with spreading crown, gray, cracked bark. Leaves are oblong, indistinctly lobed. The trichomes are observed only on the abaxial surface; simple-uniseriate trichomes are mainly distributed on the surface but a few stellate trichomes with $4-8$ short rays $(85-150 \mu \mathrm{m})$ are also observed (Fig. 1I). There are no tri- 
chomes on the midrib, but a few solitary and fasciculate trichomes have been observed on the midrib edges (Fig. 5H). The waxes are of the irregular platelet type, platelets are large and evenly distributed (Fig. $2 \mathrm{H}$ ). The stomata are raised and rounded, the rim is entirely covered with wax, pore is invisible (Fig. 3H).

Quercus infectoria Oliv. subsp. boissieri (Reut.) O. Schwarz var. pfaeffingeri (Kotschy ex Tchihatcheff) Jamzad et Panahi

Deciduous small tree, up to $10 \mathrm{~m}$ high, with spreading crown, narrow and slightly hairy branches turning glabrous in mature specimens. Leaves are elliptical, entire, with obtuse apex. A few sparse stellate trichomes with 4-8 rays $(110-190 \mu \mathrm{m})$, mostly completely twisted occur on both abaxial (Fig. 1J) and adaxial surfaces (Fig. 1K). Solitary and fasciculate trichomes with 2-4 long erect rays $(150-270 \mu \mathrm{m})$ are observed upon the midrib (Fig. 5I). On the midrib, a higher trichome density at the edges is observed. Irregular platelets waxes are irregularly distributed on the abaxial surface (Fig. 2I). The waxes have been eroded in some spaces especially around the stomata. The stomata are roundish and raised; the rim is uncovered (Fig. 3I).

\section{Discussion}

Our observations confirm the taxonomical usefulness of micromorphological features of the abaxial and adaxial leaf surfaces within the studied taxa. A very clear differentiation was observed for the types and number of trichome present on both abaxial and adaxial surfaces, types of epicuticular wax, shape and density of stomata and their position with respect to the leaf surface.

Regarding morphological characters and controversial nomenclature used by different authors, three species groups can be recognized in the examined taxa. The first group is formed by Quercus komarovii, Q. petraea subsp. iberica and Q. macranthera. Quercus komarovii was recorded from Iran by DJAVANCHIR (1967). He reported it in the list of lobed-leaf oak species of Iran, distributed in Arasbaran Forests, located in northwest Iran, whereas MENITSKy (1971) did not report it from Iran. From an ecological point of view, $Q$. komarovii is only present in populations mixed with $Q$. macranthera in upland forests of Arasbaran, over a range of altitudes between $1700 \mathrm{~m}$ to $2200 \mathrm{~m}$. Quercus petraea subsp. iberica grows throughout Hyrcanian Forests, located in the north of Iran. It mixes with $Q$. castaneifolia in lower altitudes and with $Q$. macranthera in upper altitudes. However, the distribution pattern of this subspecies extends to Arasbaran in NW Iran where it appears in elevations lower than $1700 \mathrm{~m}$ but separate from $Q$. komarovii. Besides, it mixes with $Q$. macranthera in some parts of the upper boundaries of its distribution area. The form of this subspecies changes to shrub in Arasbaran because of human activities and ecological factors. Quercus komarovii and Q. petraea subsp. iberica exhibit some morphological similarities, but differences in leaf shape, color of branches and shape of cup scales are recognized. The tree form is also different by its presenting a low-growing spreading crown. These similarities may have been the reason for identifying all Iranian specimens as $Q$. petraea subsp. iberica by some authors. We did not have access to $Q$. komarovii specimens from the Caucasus to compare its epidermal features with the Iranian specimens and with $Q$. petraea subsp iberica, but with the data available we considered the specimens from high altitude of Arasbaran Forest to be $Q$. komarovii. In our studies we recognized some 
epidermal features such as the number of stellate trichomes, trichome type and wax distribution on abaxial surface and around the stomata as diagnostic characters to define these species. Also both $Q$. komarovii and $Q$. petraea subsp. iberica have 2-4 rayed trichomes with more or less the same size range but in the former the middle rays of trichomes are erect and the others are appressed on lamina, while in the later species all trichome rays are spread regularly on lamina. Quercus macranthera completely differs from the other species in this group because of presence of trichomes on both abaxial and adaxial surfaces and denser fasciculate trichomes on abaxial surface.

The second group is formed by Quercus longipes and Q. robur subsp. pedunculiflora, which are more or less similar regarding to their morphological characteristics. Quercus longipes is distributed in small stands in Piranshahr and Khoy (West Azerbaijan) and Osku (East Azerbaijan), located in the west of Iran. Individuals of Q. robur subsp. pedunculiflora grow in Osku and Pessan valley of Urmia, between Baneh and Marivan (Kurdistan) and between Khoy and Tabriz. In general, this species has a wider distribution and the individual tree specimens are seen in the area of its distribution, but $Q$. longipes appears in small size populations.

Our observations showed that these taxa have distinct differences regarding to some aspects of epidermal structures. Quercus longipes has densely stellate trichomes with 2-8 short rays, while $Q$. robur subsp. pedunculiflora has sparse stellate trichomes with 2-4 longer rays. The presence of a few bulbous trichomes in $Q$. longipes is another diagnostic character which can be used for determination of this species. Furthermore, types of epicuticular waxes completely differ in these taxa. Quercus longipes has crystalloids type of wax, whereas $Q$. robur subsp. pedunculiflora has smooth layer type of wax.

Last group is formed by Quercus infectoria subsp. boissieri, Q. infectoria subsp. boissieri var. tenuicarpa, $Q$. infectoria subsp. boissieri var. pfaeffingeri and $Q$. cedrorum. Quercus infectoria subsp. boissieri has wider distribution area than the others in Northern Zagros Forests. It is the main taxon of Zagros Forests. It is widely distributed in West Azerbaijan, Kurdistan, Kermanshah and Luristan provinces. Small stands of specimens named Quercus infectoria var. tenuicarpa Djavanchir and Q. pfaeffingeri Kotschy are only distributed in Baneh, Kurdistan province, mixed with Q. infectoria subsp. boissieri. Quercus cedrorum is only found in a small forest area in West Azerbaijan, and was reported for the first time from Zagros Forests of Iran (DJAVANCHIR KHOIE 1967). This species is easily distinguished from the rest by having leaves with deep lobes, membraneous platelet waxes, markedly elliptical stomata and two types of trichomes: solitary and stellate. Fasciculate trichomes are absent in this species. Quercus infectoria var. tenuicarpa is different from $Q$. infectoria subsp. boissieri var. boissieri by having 4-8 rayed stellate trichomes, rays shorter than the typical variety, and rounded stomata completely covered by wax, so that the pore is invisible. Within this group, special attention should be devoted to $Q$. pfaeffingeri, which was recognized as a synonym of $Q$. infectoria subsp. boissieri (MENITSKy 1971). In Q. pfaeffingeri, almost all leaves are entire in an individual tree (about $5-6 \%$ with indistinctly crenate to more or less undulate margins), but in $Q$. infectoria subsp. boissieri, heterophyly can be observed and only a few entire leaves are present in an individual tree.

In addition to morphological differences, our study on epidermal structures showed distinct and obvious differences among these taxa. The main epidermal characteristics of 
Quercus pfaeffingeri are the presence of twisted stellate trichomes on the adaxial surface and roundish stomata with the rim not covered by wax.

Considering the morphological characters such as entire leaves, trichome types and stomata shape and distribution pattern we recognize it as a variety of $Q$. infectoria subsp. boissieri as stated below:

Quercus infectoria Oliv. subsp. boissieri (Reut.) O.Schwarz var. pfaeffingeri (Kotschy ex Tchihatcheff) Jamzad et Panahi comb nov. (Syn.: Q. pfaeffingeri Kotschy, op. cit. t. 23 (1860); Q. infectoria Oliv. var. pfaeffingeri Kotschy ex Tchihatcheff, Etude veget. hautes montagnes Asia mineure et Arménia, 17, 1857).

Quercus infectoria Oliv. var. tenuicarpa as a variety of subsp. boissieri as stated below: Q. infectoria Oliv. subsp. boissieri (Reut.) O.Schwarz var. tenuicarpa (Djav.-Khoie) Jamzad et Panahi comb. nov. (Syn.: Q. infectoria Oliv. subsp. boissieri (Reut.) O. Schwarz, Feddes Repert. 33: 336 (1934); Q. infectoria Oliv. var. tenuicarpa Djav.-Khoie, Chenes Iran, 172, 1967).

The results of multivariate analysis show the different positions of all examined taxa which is congruent with recognizing nine distinct taxa in Quercus sect. Quercus in Iran.

In conclusion, epidermal features are useful taxonomic characters that can help to delimit different taxa in lobed-leaf oaks of Iran. Based on foliar epidermal characters an identification key of species of lobed-leaf oaks of Iran has been prepared (Tab. 6).

Tab. 6. Key to the species of Quercus Sect. Quercus based on leaf epidermis features

1. Trichomes present on both abaxial and adaxial surfaces, Adaxial surface with a few solitary and 2 - rayed fasciculate trichomes; abaxial surface with densely $2-8$ long rays (190 - $455 \mu \mathrm{m}$ long)

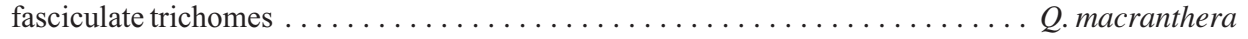

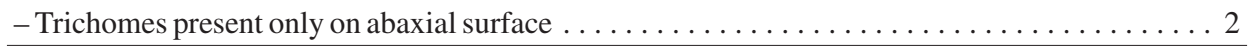

2. Abaxial surface with dense and various types of trichomes: $2-8$ (often 4) symmetric short rays $(35-70 \mu \mathrm{m}$ long) stellate, simple-uniseriate and bulbous. The stomata rim completely covered with




3. Abaxial surface with smooth layers type waxes $\ldots \ldots \ldots \ldots$ Q. robur subsp. pedunculiflora - Abaxial surface with platelets and plates type waxes, membraneous platelets or irregular platelets . 4 4. Membraneous platelets waxes with very small scales $\ldots \ldots \ldots \ldots \ldots \ldots \ldots$ Q. cedrorum

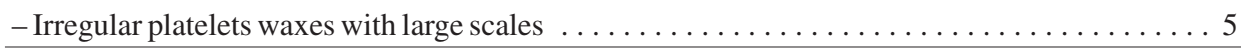

5. Stomata rim completely covered by wax, stellate trichomes with $2-5$ rays ( $90-210 \mu \mathrm{m}$ long), Q. infectoria subsp. boissieri var. boissieri

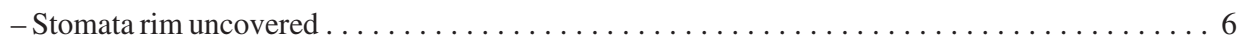

6. Abaxial leaf surface with multicellular simple-uniseriate and $2-4$ (often 4) symmetric short rayed $(75-120 \mu \mathrm{m})$ stellate trichomes, spread on regularly on the lamina, simple uniseriate trichomes are more abundant than stellate trichomes. Waxes of irregular lax platelets type with empty spaces between platelets $\ldots \ldots \ldots \ldots \ldots \ldots \ldots \ldots \ldots \ldots \ldots \ldots \ldots \ldots \ldots \ldots \ldots$. petraea subsp. iberica - Abaxial leaf surface with completely symmetric 2 - 4 (often 4 ) short rays ( 60 - $95 \mu \mathrm{m}$ ) stellate trichomes, the middle rays are erect and others appressed, roughly parallel to the epidermis. A few solitary trichomes present. Stellate trichomes are more frequent than simple uniseriate trichomes. Waxes of irregular dense platelets type .......................... karovii 


\section{Acknowledgements}

We would like to thank the authorities of Herbarium of Research Institute of Forests and Rangelands and Herbarium of Natural Recourses Faculty, Tehran University for permitting to use the herbarium specimens. Thanks are due to Mr. M. SAGHAFI for his help in preparing SEM micrographs.

\section{References}

BAČIć, T., 1981: Investigations of stomata of three oak species with light and scanning electron microscope. Acta Botanica Croatia 40, 85-90.

Barthlott, W., Neinhuis, C., Cutler, D., Ditsch, F., Meusel, I., Theisen, I., Wilhelmi, H., 1998: Classification and terminology of plant epicuticular waxes. Botanical Journal of the Linnean Society 126, 237-260.

Bruschi, P., Venderamin, G. G., Bussotti, F., Grossoni, P., 2000: Morphological and molecular differentiation between $Q$. petraea (Matt.) Liebl. and $Q$. pubescens Willd. (Fagaceae) in northern and central Italy. Annals of Botany 85, 325-333.

Bussotti, F., Grossoni, P., 1997: European and Mediterranean oaks (Quercus L.; Fagaceae): SEM characterization of the micromorphology of the abaxial leaf surface. Botanical Journal of the Linnean Society 124, 183-199.

Camus, A., 1936-1954: Les Chênes. Monographie du Genre Quercus, 3. Paul Lechevalier, Paris.

DE BARY, A., 1871: Ueber die Wachsüberzüge der Epidermis. Oesterreichische Botanische Zeitschrift 29, 128-139, 145-154, 161-176, 566-571, 573-585, 605-619.

Djavanchir Khole, K., 1967: Les chênes de l'Iran. PhD Thesis, Universite de Montpellier.

Dyal, S. C., 1936: A key to the species of oaks of eastern North America based on foliage and twig characters. Rhodora 38, 53-63.

Fortini, P., Viscosi, V., Maiuro, L., Fineschi, S., Vendramin, G. G., 2009: Comparative leaf surface morphology and molecular data of five oaks of the subgenus Quercus Oerst (Fagaceae). Plant Biosystems 143, 543-554.

Hardin, J.W., 1976: Terminology and classification of Quercus trichomes. Journal of Elisha Mitchell Science Society 92, 151-161.

HARDIN, J.W., 1979a: Atlas of foliar surface features in woody plants, I. vestiture and trichome types of eastern North American Quercus. Bulletin of Torrey Botanical Club $106,313-325$.

HARDin, J. W., 1979b: Patterns of variation in foliar trichomes of eastern North American Quercus. American Journal of Botany 66, 576-585.

JONES, J. H., 1986: Evolution of the Fagaceae: the implications of foliar features. Annals of Missouri Botanical Garden 73, 228-275.

Llamas, F., Perez-Morales, C., Acedo, C., Penas, A., 1995: Foliar trichomes of the evergreen and semi-deciduous species of the genus Quercus (Fagaceae) in the Iberian Peninsula. Botanical Journal of Linnean Society 117, 47-57. 
LutZ, A., 1938: Beiträge zur Pharmakognosie der Salicales Juglandales and Fagales. Anatomie des Laubblattes. PhD Thesis, Universitäte Basel.

Manos, P. S., 1993: Foliar trichome variation in Quercus section Protobalanus (Fagaceae). Sida $15,391-403$.

Menitsky, G. L. 1971: Fagaceae. In: Rechinger, K. H. (ed.), Flora Iranica 77, 1-20. Akademische Druk- und Verlagsanstalt, Graz.

Nikolić, N. P., Merkulov, L. S., Krstić, B. D., Orlović, S. S., 2003. A comparative analysis of stomata and leaf trichome characteristics in Quercus robur L. genotypes. Proceedings for Natural Sciences, Matica Srpska, Novi Sad, 105, 51-59.

Pénas Merino, A., Llamas, F., Perez Morales, C., Acedo, C., 1994: Aportaciones al conocimiento del genero Quercus en la Cordillera Cantabrica. I, Tricomas foliares de las especies caducifolias. Lagascalia 17, 311-324.

Safou, O., SAint-Martin, M., 1989: Leaf trichomes of some perimediterranean Quercus species. Bulletin de la Société Botanique de. France 136, 291-304.

Scareli-Santos, C., Herrera-Arroyo, M. L., Sanchez-Mondragon, M. L., Gonzalez-Rodriguez, A., BACON, J., OYAMA, K., 2007: Comparative analysis of micromorphological characters in two distantly related Mexican oaks, Quercus conzattii and $Q$. eduardii (Fagaceae) and their hybrids. Brittonia 59, 37-48.

Thamson, P. M., Mohlenbrock, R. H., 1979: Foliar trichomes of Quercus subgenus Quercus in the eastern United States. Journal of the Arnold Arboretum 60, 350-366.

Uzunova, K., Palamarev, E., 1985: The foliar epidermis studies of Fagaceae Dumort. From the Balkan Peninsula. II. Quercus [Subgenera Sclerophyllodrys Schwarz and Cerris (Spach) Oersted] (in Bulgarian). Fitologia 29, 3-20.

Uzunova, K., Palamarev, E., 1992a: Study of the leaf epidermis of the Balkan representatives of the Fagaceae Dumort. III. Quercus L. [Subgenus Quercus, sect. Roburoides (Schwarz) Schwarz and Dascia Kotschy]. Fitologia 42, 22-48.

Uzunova, K., Palamarev, E., 1992b: The foliar epidermis studies of Fagaceae Dumort. From the Balkan Peninsula. IV. Quercus L. (Subgenus Quercus, sect. Robur Reichend.). Fitologia 43, 3-30.

Uzunova, K., Palamarev, E., 1993: An investigation of the leaf epidermis of the European (non-Balkan) species of the genus Quercus. Fitologia 45, 3-15.

Uzunova, K., Palamarev, E., Ehrendorfer, F., 1997: Anatomical changes and evolutionary trends in the foliar epidermis of extant and fossil Euro-Mediterranean oaks (Fagaceae). Plant Systematics and Evolution 204, 141-159. 